\title{
Pemberdayaan Masyarakat Dalam Menciptakan Gerakan Bersih dan Mandiri Berbasis Revolusi Mental di Desa Balansiku
}

\author{
Hendy Lesmana ${ }^{1 *}$, Syahran$^{2}$, Nia Kurniasih Suryana ${ }^{3}$, Widyastuti Cahyaningrum², \\ Donny Tri Wahyudi ${ }^{1}$ \\ 1,5 Jurusan Keperawatan, Fakultas Ilmu Kesehatan Universitas Borneo Tarakan, Indonesia \\ ${ }^{2,4}$ Prodi Manajemen, Fakultas Ekonomi Universitas Borneo Tarakan, Indonesia \\ ${ }^{3}$ Prodi Agribisnis, Fakultas Pertanian, Universitas Borneo Tarakan, Indonesia \\ * hendylesmana2@gmail.com
}

\begin{abstract}
ABSTRAK
Gerakan revolusi mental adalah suatu gerakan untuk mengembleng manusia Indonesia agar menjadi manusia baru, yang berhati putih, berkemauan baja, bersemangat elang rajawali, berjiwa api yang menyala-nyala. Pada praktik kehidupan sehari-hari, gerakan revolusi mental menjadikan manusia yang berintegritas, mau berkerja keras dan memiliki semangat gotong royong. Kegiatan ini dilaksanakan di Desa Balansiku yang merupakan desa yang berada di Pulau Sebatik dan berbatasan langsung dengan Negara Malaysia, Kegiatan pengabdian bertujuan untuk meningkatkan keterampilan masyarakat dalam pemanfataan bahan/produk lokal yang dapat meningkatkan perekonomian masyrakat dan meningkatkan pengetahuan masyarakat mengenai kesehatan. Kegiatan yang dilaksanakan berupa; pelatihan pembuatan pupuk Mol berbahan lokal, pelatihan pelabelan dan tehnik kemasan yang baik pada produk olahan lokal, Sosialisasi pentingnya cuci tangan dan sikat gigi yang benar, dan Pelatihan pembuatan bak sampah keluarga. Kegiatan terlaksana dengan partisipasi masyarakat Desa balansiku yang aktif, dukungan dari Kepala Desa Balansiku, PKK Desa Balansiku, Dinas Pemberdayaan Masyarakat Kabupaten Nunukan, danMahasiswa KKN Kelompok 3 Universitas Borneo Tarakan.
\end{abstract}

Kata Kunci: Cuci tangan, Desa Balansiku, Revolusi mental, Kesehatan

Received: May, 28, 2020

Revised: June 16, 2020

Accepted: July 24, 2020

This is an open-acces article distributed under the terms of the Creative Commons Attribution-ShareAlike 4.0 International License.

\section{PENDAHULUAN}

Gerakan revolusi mental adalah suatu gerakan untuk mengembleng manusia Indonesia agar menjadi manusia baru, yang berhati putih, berkemauan baja, bersemangat elang rajawali, berjiwa api yang menyala-nyala. Pada praktik kehidupan sehari-hari, gerakan revolusi mental menjadikan manusia yang berintegritas, mau berkerja keras dan memiliki semangat gotong royong. Fokus utama dari gerakan revolusi mental di masyarakat adalah membangun jiwa merdeka, mengubah cara pandang, pikiran, sikap dan prilaku agar berorientasi pada kemajuan dan modern sehingga Indonesia menjadi Negara yang besar dan mampu berkompetisi dengan bangsa lain di dunia (KOMINFO, 2015). 


\section{Journal of Community Engagement in Health}

Provinsi Kalimantan Utara merupakan provinsi ke 34 dan termuda di Indonesia yang saat ini sedang berusaha mengejar ketertinggalan pembangunan dan kesejahteraan masyarakatnya. Provinsi Kalimantan Utara terletak di paling utara Pulau Kalimantan dan sekaligus merupakan wilayah perbatasan dengan Negara Malaysia (Sabah dan Serawak). Provinsi Kalimantan Utara memiliki kekayaan Sumber daya alam yang melimpah dan mempunyai potensi terus berkembang. Desa Balansiku berdiri menjadi sebuah desa pada tanggal 8 Maret 2010 berdasarkan peraturan Daerah Nomor 3 Tahun 2010 yang merupakan pemekaran dari desa Tanjung Karang. Pada Tanggal 23 Oktober 2010 Desa Balansiku pertamakali melakukan pemilihan Kepada Desa dengan hasil terpilihnya Bapak H. Firman H. Latif sebagai kepala desa pertama dan dilantik pada tanggal 01 November 2010. Desa Balansiku memiliki luas 2.385,70 ha dengan Koordinat bujur $117^{\circ} 510-11753^{\circ}$. Jumlah penduduk Desa Balansiku berdasarkan profil desa Tahun 2016-2017 sebanyak 1.369 jiwa dengan jumlah kepala keluarga $343 \mathrm{KK}$, terdiri dari 712 laki-laki dan 657 perempuan. Mayoritas penduduk Desa Balansiku beragama Islam, dengan mata pencarian terbanyak dari sektor pertanian, perkebunan, peternakan, dan perikanan sehingga perkebunan kelapa sawit merupakan penggerak perekonomian keluarga terbesar di Desa ini.

Sektor pertanian dan perkebunan merupakan sektor penunjang perekonomian masyarakat Desa Balansiku. Hasil utama perkebunan meliputi kepala sawit, kakao, langsat, durian, elai, cempedak, dan rambutan. Sebagian besar wilayah Desa Balansiku terdiri dari lahan perkebunan dan pertanian. kelapa sawit, kakao, pisang, jeruk, dan rumput laut sehingga perkebunan kelapa sawit merupakan roda penggerak perekonomian terbesar di desa ini. Ini bisa dilihat dari total luas Wilayah Desa Balansiku 2.385,70 ha. Berdasarkan hasil pengkajian dilakukan dilapangan maka permasalahan yang di temukan meliputi: (1) Kurangnya pengetahuan masyarakat mengenai pemanfaatan potensi lokal guna menumbuhkan kewirausahaan masyarakat dan (2) Kurangnya kesadaran masyarakat akan pentingnya kesehatan lingkungan dengan tidak membuang sampah sembarang tempat dan perilaku hidup bersih dan sehat. Guna mengatasi permasalahan tersebut, maka kegiatan yang dilaksanakan meliputi ; (1) pendampingan masyarakat dalam pemanfataan bahan/produk lokal yang dapat meningkatkan perekonomian masyrakat melalui kegiatan; pelatihan pembuatan pupuk MOL berbahan lokal dan pelatihan pelabelan dan tehnik kemasan yang baik pada produk olahan lokal. (2) peningkatan pengetahuan masyarakat mengenai kesehatan dalam bentuk kegiatan; sosialisasi pentingnya cuci tangan dan sikat gigi yang benar, pelatihan pembuatan bak sampah keluarga.

\section{BAHAN DAN METODE}

Kegiatan pngabdian masyarakat ini dilaksanakan dengan metode ceramah, simulasi dan praktik langsung, baik kegiatan pembuatan pupuk MOL berbahan lokal, pelatihan pelabelan dan tehnik kemasan yang baik pada produk lokal, sosialisasi pentingnya cuci tangan dan sikat gigi yang benar, dan pelatihan pembuatan bak sampah keluarga. Sasaran peserta pelatihan adalah masyarakat Desa Balansiku, Kecamatan Sebatik, Kabupaten Nunukan, Provinsi Kalimantan Utara. Kegiatan ini terlaksana karena dukungan dari Kades Balansiku, Camat Sebatik, Ketua PKK Desa Balansiku, Dinas Pemberdayaan Masyarakat Desa Kabupaten Nunukan, dan Mahasiswa KKN Kelompok 3 Tahun 2019 Universitas Borneo Tarakan. 


\section{Journal of Community Engagement in Health}

http://jceh.org

ISSN: 2620-3758 (print); 2620-3766 (online)

https://doi.org/10.30994/jceh.v3i2.54

Vol.3 No.2. Sep 2020. Page.151-157

\section{HASIL}

Kegiatan pemberdayaan masyarakat dalam menciptakan gerakan bersih dan mandiri berbasis revolusi mental terdiri dari;

1) Pendampingan masyarakat dalam pemanfataan bahan/produk lokal yang dapat meningkatkan perekonomian masyrakat

Kegiatan pendampingan masyarakat dalam pemanfataan bahan/produk lokal yang dapat meningkatkan perekonomian masyrakat terdiri dari dua kegiatan yakni;

(1) Pelatihan pembuatan pupuk MOL berbahan lokal

Kegiatan pelatihan ini dilaksanakan pada tanggal 8 Pebruari 2019 bertempat di AULA Kantor Desa Balansiku. Kegiatan ini dilakukan dengan melibatkan Tokoh-Tokoh Masyarakat, murid-murid sekolah SMP Negeri 2 Sebatik serta masyarakat yang ada di Desa Balansiku baik berprofesi sebagai petani maupun bukan petani. Tujuan dari kegiatan ini yaitu untuk mengajarkan masyarakat agar dapat mengolah kembali limbah rumah tangga menjadi sesuatu yang bermanfaat dan dapat menjadi sesuatu yang bernilai jual. Diharapkan setelah kegiatan ini masyarakat dapat menyiapkan untuk kebun mereka sendiri sehingga dapat mengurangi kerusakan struktur tanah dan menjaga kelembaban tanah agar tetap baik.

(2) Pelatihan pelabelan dan tehnik kemasan yang baik pada produk olahan lokal.

Kegiatan ini dilaksanakan pada tanggal 15 Pebruari 2019 bertempat di AULA Kantor Desa Balansiku. Kegiatan ini dilakukan berdasarkan kurangnya kesadaran masyarakat akan pentingnya pelabelan dan pengemasan dalam produk yang mereka hasilkan. Kegiatan ini melibatkan ibu PKK, KUBE dan kegiatan ini bekerjasama dengan Dinas Pemberdayaan Masyarakat Desa (DPMD) Kabupaten Nunukan. Tujuan dari kegiatan ini agar masyarakat dapat memberikan label dan kemasan yang baik pada produk olahan lokal desa Balansiku. Setelah kegiatan ini diharapkan agar masyarakat sekitar memiliki produk yang sudah diberikan label dan memiliki kemasan produk yang baik.

2) Peningkatan pengetahuan masyarakat mengenai kesehatan

Kegiatan peningkatan pengetahuan masyarakat mengenai kesehatan terdiri dari dua kegiatan yakni;

(1) Sosialisasi pentingnya cuci tangan dan sikat gigi yang benar

Salah satu kegiatan dari penerapan Prilaku Hidup Bersih Dan Sehat (PHBS) adalah prilaku cuci tangan dan menggosok gigi seperti kegiatan yang di terapkan di halaman sekolah SD Negeri 002 Sebatik yang beralamat di Desa Balansiku. Kegiatan ini dilaksanakan pada tanggal 1 Pebruari 2019, guna melihat bagaimana keseharian murid murid SD yang tidak mencuci tangan sebelum makan dan sering mengkonsumsi makanan yang manis tanpa memperhatikan kesehatan gigi mereka, dan sasarannya adalah murid SD baik yang ada di Desa Balansiku. Setelah dilakukannya kegiatan ini di harapkan murid murid SD dapat mencuci tangan mereka dengan baik dan selalu memperhatikan kesehatan gigi mereka dengan cara menggosok gigi dengan benar.

(2) Pelatihan pembuatan bak sampah keluarga

Kegiatan pembuatan bak sampah bertujuan untuk meningkatkan kesadaran masyarakat akan pentingnya kebersihan lingkungan, yang dapat meningkatkan derajat kesehatan keluarga. Kegiatan ini dilaksanakan pada tanggal 23 Januari 2019, bertempat di 


\section{Journal of Community Engagement in Health}

http://jceh.org

ISSN: 2620-3758 (print); 2620-3766 (online)

https://doi.org/10.30994/jceh.v3i2.54

Vol.3 No.2. Sep 2020. Page.151-157

Desa Balansiku yang dihadiri oleh warga masyarakat Desa Balansiku. Peserta yang merupakan warga Desa Balansiku mengikuti kegiatan ini dari awal hingga akhir, dimana kegiatan ini diawali dengan metode demontrasi dan kemudian di praktikan secara langsung oleh warga. Hasil kegiatan ini dalam bentuk tong sampah yang di letakkan di beberapa lokasi strategis di Desa Balansiku.

\section{PEMBAHASAN}

1) Pendampingan masyarakat dalam pemanfataan bahan/produk lokal yang dapat meningkatkan perekonomian masyrakat

Kegiatan pendampingan masyarakat dalam pemanfataan bahan/produk lokal yang dapat meningkatkan perekonomian masyrakat terdiri dari dua kegiatan yakni;

(1) Pelatihan pembuatan pupuk MOL berbahan lokal

Mayoritas masyarakat yang berada di Desa Balansiku dan Desa Sei Manurung berprofesi sebagai petani dan berkebun, dimana untuk Desa Balansiku jumlah penduduk yang berprofesi sebagai petani berjumlah 363 orang dan yang berkebun sebanyak 174 orang jumlah penduduk keseluruhan 1.369 jiwa dengan 343 KK. Desa Sei manurung dengan jumlah penduduk sebanyak 923 jiwa dengan $238 \mathrm{KK}$, jumlah penduduknya berprofesi sebagai petani sebesar 188 orang dan buruh tani sebanyak 32 orang. Tingkat pengetahun masyarakat tentang tehnologi Bertani dengan pemanfaatan bahan lokal masih sangat kurang sehingga kami berinisiatif untuk melatih masyarakat bagaimana memanfaatkan bahan lokal untuk meningkatkan hasil pertanian dan perkebunan masyarakat.

Pupuk Mikroorganisme Lokal (MOL) adalah mikroorganisme yang dimanfaatkan sebagai starter dalam pembuatan pupuk organic baik berbentuk padat maupun cair. Bahan dasar pembuatan pupuk MOL ini bisa dari hasil pertanian, perkebunan, maupun limbah organik rumah tangga. Hasil pertanian dapat berasal dari sayur-sayuran, sumber dari perkebunan dapat berasal dari singkong, gandum, daun gamal. Limbah rumah tangga juga dapat dimanfaatkan sebagai bahan dasar pembuatan pupuk MOL seperti; air cucian beras, gula merah dan air kelapa.

Tumbuhan yang banyak terdapat di sekitar Desa Balansiku dan Desa Sei Manurung adalah sayur kangkung. Sehingga untuk memanfaatkan potensi lokal yang ada di desa tersebut sebagai bahan dasar pembuata pupuk MOL, maka kami mengajarkan pembuatan pupuk MOl berbahan dasar sayur kangkung.

Tehnik pembuatan pupuk MOL dengan bahan sayur kangkong yakni; cincang halus kangkung tersebut, bahan ini bisa ditambah dengan gula merah yang terlebih dahulu di panaskan dengan air. Bila tidak menggunakan air gula merah, dapat menggantikannya dengan air cucian beras. Campurkan kangkung yang sudah dihaluskan dengan air gula merah atau air cucian beras, kemudian simpan dalam wadah tertutup dan diamkan selama 14 hari. Sesekali dapat di aduk dan di buka tutupnya untuk mengelurkan gas fermentasi lalu tutup rapat lagi. Setelah 14 hari cairan ini di saring, ampas nya bisa dimanfaatkan sebagai pupuk kompos sedangkan cairannya dapat digunakan sebagai pupuk MOL. Cara penggunaan pupuk MOL ini dapat disiram ke tanaman dengan frekuensi 1 minggu sekali.

Kegiatan ini dilakukan dengan melibatkan Tokoh-Tokoh Masyarakat, murid-murid sekolah SMP Negeri 2 Sebatik serta masyarakat sekitar serta bantuan dari Mahasiswa KKN kelompok 3 Universitas Borneo Tarakan. Tujuan dari kegiatan ini yaitu untuk mengajarkan masyarakat agar dapat mengolah kembali limbah rumah tangga menjadi sesuatu yang bermanfaat dan dapat menjadi sesuatu yang bernilai jual. Diharapkan setelah 


\section{Journal of Community Engagement in Health}

http://jceh.org

ISSN: 2620-3758 (print); 2620-3766 (online)

https://doi.org/10.30994/jceh.v3i2.54

Vol.3 No.2. Sep 2020. Page.151-157

kegiatan ini masyarakat dapat menyiapkan untuk kebun mereka sendiri sehingga dapat mengurangi kerusakan struktur tanah dan menjaga kelembaban tanah agar tetap baik.

(2) Pelatihan pelabelan dan tehnik kemasan yang baik pada produk olahan lokal.

Pengemasan merupakan salah satu cara untuk melindungi atau mengawetkan produk pangan maupun non-pangan. Kemasan adalah suatu wadah atau tempat yang digunakan untuk mengemas suatu produk yang dilengkapi dengan label atau keterangan-keterangan termasuk beberapa manfaat dari isi kemasan. Pengemasan mempunyai peranan dan fungsi yang penting dalam menunjang distribusi produk terutama yang mudah mengalami kerusakan.

Fungsi kemasan adalah sebagai wadah atau tempat produk, sebagai pelindung bagi produk yang dikemas, kemasan juga berfungsi untuk melindungi lingkungan sekitar produk, sebagai penunjang cara penyimpanan dan transport dan sebagai alat persainagn dalam pemasaran.

Syarat kemasan yang harus dipenuhi oleh produsen makanan adalah; 1) tidak toksik, dimana kemasan tidak mengganggu kesehatan secara langsung maupun tidak langsung. 2) harus cocok dengan bahan yang dikemas; kemasan yang dipilih harus cocok dengan produk yang dikemas, karena bila salah memilih bahan kemasan maka dapat merugikan produsen. 3) Sanitasi dan syarat-syarat kesehatan terjamin; Disamping bahan kemasan tidak toksik dan produk yang dikemas tidak menunjukkan kerusakan karena serangan mikroba, juga bahan kemasan tidak boleh digunakan bila dianggap tidak dapat menjamin sanitasi atau syarat-syarat kesehatan.

Kegiatan ini melibatkan ibu PKK, KUBE dan kegiatan ini bekerjasama dengan Dinas Pemberdayaan Masyarakat Desa (DPMD) Kabupaten Nunukan serta mahasiswa KKN kelompok 3 Universitas Borneo Tarakan sebagai fasilitator sehingga kegiatan ini dapat terlaksana dengan baik. Tujuan dari kegiatan ini agar masyarakat dapat memberikan label dan kemasan yang baik pada produk olahan lokal desa Balansiku. Setelah kegiatan ini diharapkan agar masyarakat sekitar memiliki produk yang sudah diberikan label dan memiliki kemasan produk yang baik.

2) Peningkatan pengetahuan masyarakat mengenai kesehatan

Kegiatan peningkatan pengetahuan masyarakat mengenai kesehatan terdiri dari dua kegiatan yakni;

(1) Sosialisasi pentingnya cuci tangan dan sikat gigi yang benar

Perilaku hidup bersih dan sehat adalah sekumpulan perilaku yang dipraktikkan atas dasar kesadaran dari hasil pembelajaran yang menjadikan seseorang atau keluarga dapat menolong dirinya sendiri di bidang kesehatan dan berperan aktif dalam mewujudkan kesehatan masyarakat. PHBS sebaiknya dimulai dari tatanan sekolah dasar karena sekolah dipandang sebagai sebuah tempat yang strategis untuk mempromosikan kesehatan dan akan lebih tertanam lebih baik dan lebih lama apabila mulai ditanamkan sejak usia dini. Selain itu, usia sekolah termasuk kedalam kelompok usia dini yang merupakan masa keemaasan untuk menanamkan nilai-nilai PHBS dan berpotensi sebagai agent of change untuk mempromosikan PHBS baik di lingkungan sekolah, keluarga, dan masyarakat.

Kegiatan ini mendapat dukungan dari kepala sekolah dan guru SDN 002 Sebatikserta mendapatkan bantuan dari Mahasiswa KKN kelompok 3 dari Universitas Borneo Tarakan. Selama kegiatan berlangsung semua murid berpartisipasi aktif dan mempraktikan secara langsung tehnik 6 langkah cuci tangan serta cara menyikat gigi dengan benar. Selama 


\section{Journal of Community Engagement in Health}

http://jceh.org

ISSN: 2620-3758 (print); 2620-3766 (online)

https://doi.org/10.30994/jceh.v3i2.54

Vol.3 No.2. Sep 2020. Page.151-157

kegiatan berlangsung guru-guru SDN 002 Sebatik beserta mahasiswa KKN Kelompok 3 Universitas Borneo membantu kegiatan ini.

(2) Pelatihan pembuatan bak sampah keluarga

Sampah merupakan sisa pakai dari kemanfaatan yang digunakan oleh kebutuhan manusia. Sampah seringkali dipandang sebagai sesuatu yang tidak ada manfaatnya. Sampah dipersepsikan sebagai sesuatu yang tidak mempunyai nilai. Secara umum, manusia menganggap sampah adalah barang sisa dari aktifitas manusia dan keberadaannya mengganggu estetika lingkungan. (Satori, Amarani, \& Shofi, 2010).

Meningkatnya nilai konsumsi masyarakat perkotaan dalam memenuhi kebutuhan hidupnya, menjadi penyumbang dari semakin banyaknya sampah yang harus dibuang. Sampah rumah tangga tidak dapat dianggap kecil dalam kapasitas penyumbang sampah bagi lingkungan. Pertumbuhan manusia yang setiap tahun meningkat, tidak luput dari penyumbang sampah terbesar di berbagai daerah. Hal itu dipengaruhi oleh lingkungan dan karakter masyarakat yang menjadi problem penting dalam memahami dan mengimplementasikan penanganan sampah bagi suatu daerah. Bertambahnya sampah sejalan dengan meningkatnya pembangunan infrastruktur dan meningkatnya pertumbuhan manusia tanpa diimbangi dengan pola penanganan dan pengelolaan sampah dengan sarana dan prasaran yang memadai. (Sudiran, 2005).

Selama kegiatan ini berlangsung, peserta yang dihadiri oleh masyarakat Desa Balansiku secara aktif mempraktikan cara pembuatan tong sampah dan Mahasiswa KKN Kelompok 3 Universitas Borneo Tarakan sangat aktif mendampingi masyarakat dalam membuat tong sampah.

\section{KESIMPULAN}

Kegiatan bimbingan teknis/pendampingan masyarakat dalam menemukan bahan lokal yang dapat meningkatkan perekonomian warga, dalam bentuk kegiatan pelatihan pembuatan pupuk MOL dengan memanfaatkan bahan lokal yakni sayur kangkung. Kegiatan kedua adalah pelatihan pelabelan dan tehnik kemasan yang baik pada produk olahan local dimana yang menjadi sasaran dalam pelatihan ini adalah ibu PKK, KUBE dan para ibu-ibu yang ada di Desa Balansiku.

Kegiatan aktivitas pendukung seperti pelayanan dan kemandirian yang akan berdampak meningkatnya kesadaran akan kemandirian masyarakat terhadap kebersihan desa yang akan berdampak pada keluarga dan masyarakat. Kegiatan terdiri dari 2 yakni; sosialisasi pentingnya cuci tangan dan sikat gigi yang benar, dan pelatihan pembuatan bak sampah keluarga

\section{REFERENSI}

Badan Pusat Statistik Kabupaten Nunukan. (2018). Kabupaten Nunukan Dalam Angka 2018. BPS Kabupaten Nunukan.

Instruksi Presiden Republik Indonesia Nomor 12 Tahun 2016. Gerakan Revolusi Mental.

Kementrian Koordinator Bidang Pembangunan Manusia Dan Kebudayaan. (2015). Sosialisasi Gerakan Nasional Revolusi Mental. Disampaikan di Jakarta Tanggal 21 Agustus 2015. 
Kementrian Koordinator Bidang Pembangunan Manusia Dan Kebudayaan. Seri 2. Buku Saku. (2015). Panduan Umum Gerakan Nasional Revolusi Mental KKN Tematik Rovolusi Mental. Jakarta. 2017.

Kementrian Komunikasi dan Informatika. (2015). Revolusi Mental: Membangun Jiwa Merdeka Menuju Bangsa Besar. Diunduh pada 10 Juni 2019 dari https://www.kominfo.go.id/content/detail/5932/revolusi-mental$\% 20$ memba\%20\%20ngun-jiwa-merdeka-menuju-bangsa-besar.

Satori, Mohamad, Amarani, Reni, Shofi, Dan Dewi. (2010). Pendampingan Usaha Masyarakat Dalam MemanfaatkanSampah Di Desa Manis Lor Kabupaten Kuningan. Prosiding SNaPP Edisi Eksakta. Universitas Islam Bandung. ISBN: 2089.3582. Hal. 150-179.

Sudiran, FL. (2005). Instrumen Sosial Masyarakat Karangmumus Kota Samarinda Dalam Penanganan Sampah Domestik. JurnalMakara, Sosial Humaniora, Volume 9, Nomor 1, Hal. 16-26. 